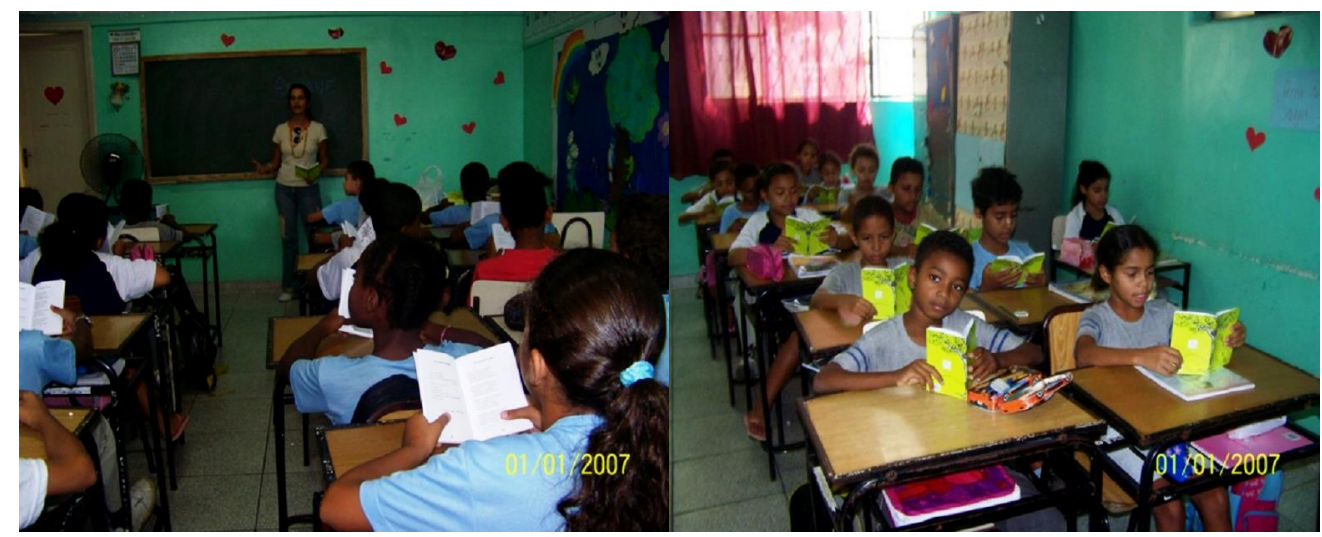

Fotos realizadas durante a oficina

\title{
QUANDO COMPRAR UM LIVRO SE TORNA UMA ATITUDE INCLUSIVA
}

\section{Rejane H Neves}

Formada em Letras, licenciatura plena em língua portuguesa, pela UNI-BH. Cursou extensão universitária em Neurolinguística e Introdução à semiótica. Atualmente, cursa na UFMG, especialização em Ensino de Leitura e Produção de Textos e especialização em Temas Filosóficos. Coordenadora do Setor Verde do Programa A tela e o texto.

Sempre estive envolvida em tarefas voluntárias, mas confesso que participar do Programa $A$ tela e o texto tem sido um aprendizado muito engrandecedor: mais que auxílio ao próximo, tem sido uma auto-educação. Uma experiência recente fascinoume.

A convite da Professora Renata, que conhece e gosta dos projetos do Programa, fui ministrar uma oficina de leitura para seus alunos do $4^{\circ}$. ano de escolaridade da Escola Estadual Professor José Mesquita de Carvalho. Marcamos a data, ela comunicou aos alunos e enviou bilhete aos pais sugerindo que comprassem o livro Folhas verdes para melhor acompanhar a oficina que foi preparada utilizando essa obra. Trata-se de publicação da Linha editorial Tela e Texto, sendo vendido a R\$1,99, para viabilizar o acesso à literatura brasileira.

No dia da oficina, dos vinte e cinco alunos presentes, dezessete compraram o livro. A satisfação deles era enorme quando receberam seus exemplares. Folhearam atentamente o livro, fazendo perguntas e comentários sobre ele. Acredito que, para a maioria desses meninos, esse era o primeiro livro 
que compravam e pude perceber uma valorização diferenciada do objeto adquirido. Mais do que um incentivo à leitura houve uma inclusão social, uma valorização da auto-estima, já que o acesso à compra de livros é muito restrito em nosso país, devido ao alto custo do produto.

Pois bem, escolhi um poema para o trabalho. Os alunos participaram com entusiasmo da análise e da discussão. Foi gratificante perceber como eles se interessaram pelos debates sobre meio ambiente. Depois, em grupos, eles fizeram um cartaz onde reescreveram o que foi debatido.

Observei que eles estavam lendo os outros poemas, comentando entre eles, interagindo com o livro. Ao final, apresentei toda a coleção dos livros de bolso que compõem a literatura de baixo custo do Programa $A$ tela e o texto. Então, um aluno aproximou-se dizendo que queria presentear sua mãe com um livro e perguntando se poderia pagar parcelado: tinha setenta centavos no momento e depois pagaria o restante. Argumentou que não poderia pedir dinheiro a sua mãe, pois não seria legal ela pagar seu próprio presente. Claro que nossa resposta foi positiva e ele se sentiu valorizado e respeitado.

Como despedida, recebi muitos beijos, abraços e um carinhoso bilhete. Acreditem, nessa aula a aprendiz fui eu!

No dia seguinte, liguei para a professora Renata pra saber da repercussão do trabalho com os livrinhos e ela respondeu que foi muito positiva. Mais três alunos compraram o livro e alguns perguntaram se eu voltaria à escola: forte indício de que a iniciativa agradou. Ficaram de combinar outra data para me convidarem novamente. Renata disse que os alunos estavam lendo o livro, colorindo os animais que ilustram os textos e comentando o debate. Contou-me também que um dos alunos confessou que gostou tanto do livro que queria tomar banho com ele.

Acho que, para uma primeira compra cultural, o registro que ficará na memória deles será de uma experiência positiva e agradável, pois houve um exercício de cidadania que resultou na auto-valorização.

A emoção que vivi não consigo descrever... Estou muito agradecida à professora e a seus alunos por essa experiência que gostaria de reviver com outros estudantes. 